\title{
The Effects of Border Shutdowns on the Spread of COVID-19
}

\author{
Nahae Kang, Beomsoo Kim \\ Department of Economics, Korea University, Seoul, Korea
}

Objectives: At the beginning of the coronavirus disease 2019 (COVID-19) pandemic, some countries imposed entry bans against Chinese visitors. We sought to identify the effects of border shutdowns on the spread of the COVID-19 outbreak.

Methods: We used the synthetic control method to measure the effects of entry bans against Chinese visitors on the cumulative number of confirmed cases using World Health Organization situation reports as the data source. The synthetic control method constructs a synthetic country that did not shut down its borders, but is similar in all other aspects.

Results: Six countries that shut down their borders were evaluated. For Australia, the effects of the policy began to appear 4 days after implementation, and the number of COVID-19 cases dropped by $94.4 \%$. The border shutdown policy took around 13.2 days to show positive effects and lowered COVID-19 cases by $91.7 \%$ on average by the end of February.

Conclusions: The border shutdowns in early February significantly reduced the spread of the virus. Our findings are informative for future planning of public health policies.

Key words: Coronavirus, Pandemics, Border shutdown, Synthetic control method

\section{INTRODUCTION}

The World Health Organization (WHO) declared the coronavirus disease 2019 (COVID-19) to be a pandemic on March 11, 2020. The first case was reported on November 17, 2019 in Hubei, China [1]. Severe acute respiratory syndrome coronavirus 2 (SARS-CoV-2), the virus that causes COVID-19, is thought to have jumped from an animal host to humans [2]. By January 23, 2020, 17 deaths and 571 confirmed cases were reported in China [3], and on January 23, 2020, the Chinese government

Received: July 17, 2020 Accepted: August 20, 2020

Corresponding author: Beomsoo Kim, PhD

Department of Economics, Korea University, 145 Anam-ro,

Seongbuk-gu, Seoul 02841, Korea

E-mail: kimecon@korea.ac.kr

This is an Open Access article distributed under the terms of the Creative Commons Attribution Non-Commercial License (https://creativecommons.org/licenses/by$\mathrm{nc} / 4.0 /$ ) which permits unrestricted non-commercial use, distribution, and reproduction in any medium, provided the original work is properly cited. locked down Wuhan and other cities in Hubei to contain the COVID-19 outbreak [4,5] (Supplemental Material 1). The shutdown of Wuhan delayed the arrival of the coronavirus in other cities in China by 3 days [6].

The number of confirmed cases in China increased dramatically compared to the rest of the world until the end of February (Supplemental Material 1). Fifty-five countries had confirmed cases as of February 29, 2020.

Various policy options exist to control the spread of a virus, and border shutdowns are a relatively extreme policy tool that can be considered. Travel restrictions have been implemented previously, although to a more limited extent. For example, during the $2009 \mathrm{H} 1 \mathrm{~N} 1$ pandemic, travel bans to and from Mexico, screening of travelers on entry into airports, and travel advisories against non-essential travel to Mexico were put into place [7]. The rapid spread of the Ebola outbreak in West Africa in 2014 led a number of countries and airline companies to issue travel bans to the affected areas [8]. Studies in the litera- 
ture used computational models to estimate the effects of these travel bans and found that they led to significant delays [7-9]. Based on these previous studies, some countries began to impose entry bans to counteract the spread of COVID-19. Kuwait was the first country to impose such a policy, on January 31, 2020 [10]. A total of 15 countries imposed entry bans on Chinese visitors by the end of February. Among these 15 countries, 6 had confirmed cases by the time they imposed entry bans on Chinese visitors: Australia (February 1, 2020) [11], Singapore (February 2, 2020) [12], the United States (February 2, 2020) [13], Vietnam (February 3, 2020) [14], Taiwan (February 7, 2020) [15], and Hong Kong (February 8, 2020) [16]. The remaining countries did not have any confirmed cases (Oman, Kuwait, Bahrain, Israel, New Zealand, and Iraq) [10,17-21] or had only 2 confirmed cases (the Philippines, Russia, and Lebanon) [22-25]. Shutting down the border might be a costly decision. Therefore, measuring the benefits of these policies is very important. Herein, we evaluated the effects of imposing entry bans on Chinese visitors using the synthetic control method.

\section{METHODS}

\section{Synthetic Control Method}

The synthetic control method, which was originally developed by Abadie and Gardeazabal [26], is used to estimate the effects of an intervention of interest using a weighted combination of untreated units. Even if the sample size is small, the combination of control units provides a more valid analysis than the results of a single control group. In contrast to the traditional regression approach, the synthetic control method has transparency against extrapolation [27]. It has been used to estimate the effects of terrorist activity on economic growth, tobacco control programs on tobacco sales, and the imposition of new health care reimbursement schemes - such as qualityadvancement programs - on mortality $[28,29]$. These methods attempt to model a counterfactual situation related to an event, and the situation evaluated in this paper perfectly fits this approach. For example, in this work, we sought to model Australia if it had not closed its borders to Chinese visitors on February 1, 2020. To do this, the synthetic control method was used to construct a synthetic Australia using the pre-intervention time period between January 21, 2020 and January 31, 2020. Possible candidates for a synthetic Australia are countries that had confirmed COVID-19 cases by the end of February, but did not shut down their borders to Chinese visitors.
Table 1. List of countries that imposed an entry ban for Chinese visitors by February 29, 2020

\begin{tabular}{lcc}
\hline Country & $\begin{array}{c}\text { Date of entry } \\
\text { ban in 2020 }\end{array}$ & $\begin{array}{c}\text { Cumulative no. of confirmed cases } \\
\text { on the date of the entry ban }\end{array}$ \\
\hline Australia & Feb 1 & 12 \\
Singapore & Feb 2 & 18 \\
USA & Feb 2 & 8 \\
Vietnam & Feb 3 & 8 \\
Taiwan & Feb 7 & 16 \\
Hong Kong & Feb 8 & 26 \\
\hline
\end{tabular}

Some countries in the possible donor pool for the synthetic model, such as Korea and Italy, experienced a spike in confirmed cases and themselves became a source of viral spread. To minimize these confounding effects of other viral sources, we used a period extending to the end of February, when China was the only source. The possible synthetic donor pool comprised the 39 countries shown in Supplemental Material 2.

The synthetic control method constructs a synthetic country using the cumulative confirmed cases during the pre-intervention period and various factors that determine the spread of the virus. If there are no cumulative confirmed cases, or only a very small number of cases by the time of the policy intervention, we cannot properly construct a synthetic country. Therefore, we excluded countries with 2 or fewer confirmed cases by the time of the policy intervention, and focused on the 6 countries listed in Table 1. The cumulative number of confirmed cases by the intervention date ranged from 8 to 26 . The intervention date of these 6 countries varied from February 1, 2020 to February 8, 2020.

In addition to the cumulative number of confirmed cases, other factors that affect the spread of the virus include demographic factors, economic factors, the healthcare environment, and the number of Chinese visitors. The demographic factors analyzed herein were the total population and the percentage of the population aged $\geq 65$. The economic situation was reflected by using gross national income (GNI) per capita. Health conditions and the healthcare environment were captured by life expectancy at birth, percentage of gross domestic product (GDP) spent on health expenditures, and the number of physicians per 1000 people.

\section{Data}

The cumulative numbers of confirmed cases were collected using WHO situation reports [30]. The report included 10 cases from the Diamond Princess cruise ship for Japan on February 5 , 
2020. We recalculated the cumulative number of cases for Japan, including the Diamond Princess cruise ship, based on the true date of confirmation. Data from the World Bank were used to determine the total population, the percentage of the population aged $\geq 65$, GNI per capita, life expectancy at birth, the percentage of GDP spent on health expenditures, and the number of physicians per 1000 people. The most recent World Bank data are from 2018 [31]. Since the World Bank data do not include Taiwan, we used national statistics from the Republic of China for Taiwan [32] and collected information from 2018. Information on the healthcare environment of Hong Kong was obtained from the Department of Health and the Food and Health Bureau [33,34], and data from 2018 are the latest available.

One of the most important factors contributing to the spread of SARS-CoV-2 may have been the number of Chinese visitors who brought the virus into the country. The Yearbook of Tourism Statistics presents the number of Chinese visitors to each country in 2018 [35]. Since Chinese visitors to Pakistan were not reported in the yearbook, we used a separate source [36].

\section{Ethics Statement}

This study did not require ethical approval because it used public data and did not involve human participants.

\section{RESULTS}

In this section, we present the effects of the entry ban for Chinese visitors on the cumulative number of confirmed cases of COVID-19 for the 6 countries (Supplemental Material 3) listed in Table 1. The results for Australia, which imposed an entry ban on February 1, 2020, are shown in Figure 1A. Australia confirmed the first 3 cases on January 25, 2020 and the cumulative number of confirmed cases had reached 12 when the entry ban for Chinese visitors was imposed. The number of cumulative confirmed cases was 15 on February 7, 2020 and remained steady for the next 13 days. The number of cumulative confirmed cases reached 24 by the end of February. In Figure $1 \mathrm{~A}$, the dotted line shows the number of cumulative confirmed cases for synthetic Australia. Synthetic Australia had 15 cumulative confirmed cases on February 5, 2020, which then exponentially increased. On February 17, 2020, the number of cumulative cases without an entry ban for Chinese visitors increased above 200, which is our maximum on the graph. By the end of February, this number was 425 compared to the actual number of 24 . In the comparison between real and syn- thetic Australia, all variables were similar. Synthetic Australia was made up of a combination of Japan (44.8\%), Norway (34.8\%), and United Arab Emirates (20.4\%).

Figure $2 \mathrm{~A}$ presents the number of infected cases avoided by the entry ban for Chinese visitors, which is the difference between synthetic Australia (without an entry ban) and real Australia (with an entry ban). The vertical dotted line on February 1, 2020 indicates the date of the policy. Before the policy intervention, there was almost no difference between real and synthetic Australia, which confirms that synthetic Australia was well constructed. The effects of the policy began to appear 4 days after it was implemented, as real Australia had 2.8 fewer cases. This increased to 401 fewer cases by the end of February, corresponding to a 94.4\% decrease in infected cases: 425 (synthetic Australia) versus 24 (real Australia).

Singapore imposed an entry ban on February 2, 2020. We present the results for Singapore in Figures $1 \mathrm{~B}$ and 2B. Synthetic Singapore was composed of Thailand (48.1\%), Korea (35.9\%), and San Marino (16.0\%). Figure 1B shows that during the pre-intervention period, synthetic Singapore modeled real Singapore well. The cumulative number of confirmed cases steadily increased in real Singapore. However, the cumulative cases for synthetic Singapore increased slowly until February 20,2020 , when they exponentially increased. As a result, the number of avoidable cases was temporarily negative and then became positive from February 21, 2020 onward. By the end of February, an entry ban for Chinese visitors lowered the number of cumulative cases by 1151 , which is a $91.5 \%$ decrease in infected cases: 1151 (synthetic Singapore) versus 98 (real Singapore). It took 19 days for effects of the policy to appear, but the number of avoidable cases exponentially increased.

We also present the results for the Unite States, which implemented its policy on February 2 at 5:00 p.m. Eastern time (Figures $1 \mathrm{C}$ and $2 \mathrm{C}$ ). The WHO situation report uses Central European Summer Time (CEST), and considering the time difference, the United States's entry ban for Chinese visitors went into effect on February 3, 2020 CEST. Figure 1C shows that the synthetic United States adequately modeled the real United States during the pre-intervention period (Supplemental Material 3 for lists of countries used to construct the synthetic United States). Sixteen days after the ban, the number of avoidable infected cases was 2, and by February 25, 2020, the number exceeded 50 , which is the maximum on the graph. This intervention postponed the outbreak by at least 16 days. Without the entry ban, the cumulative number of confirmed 

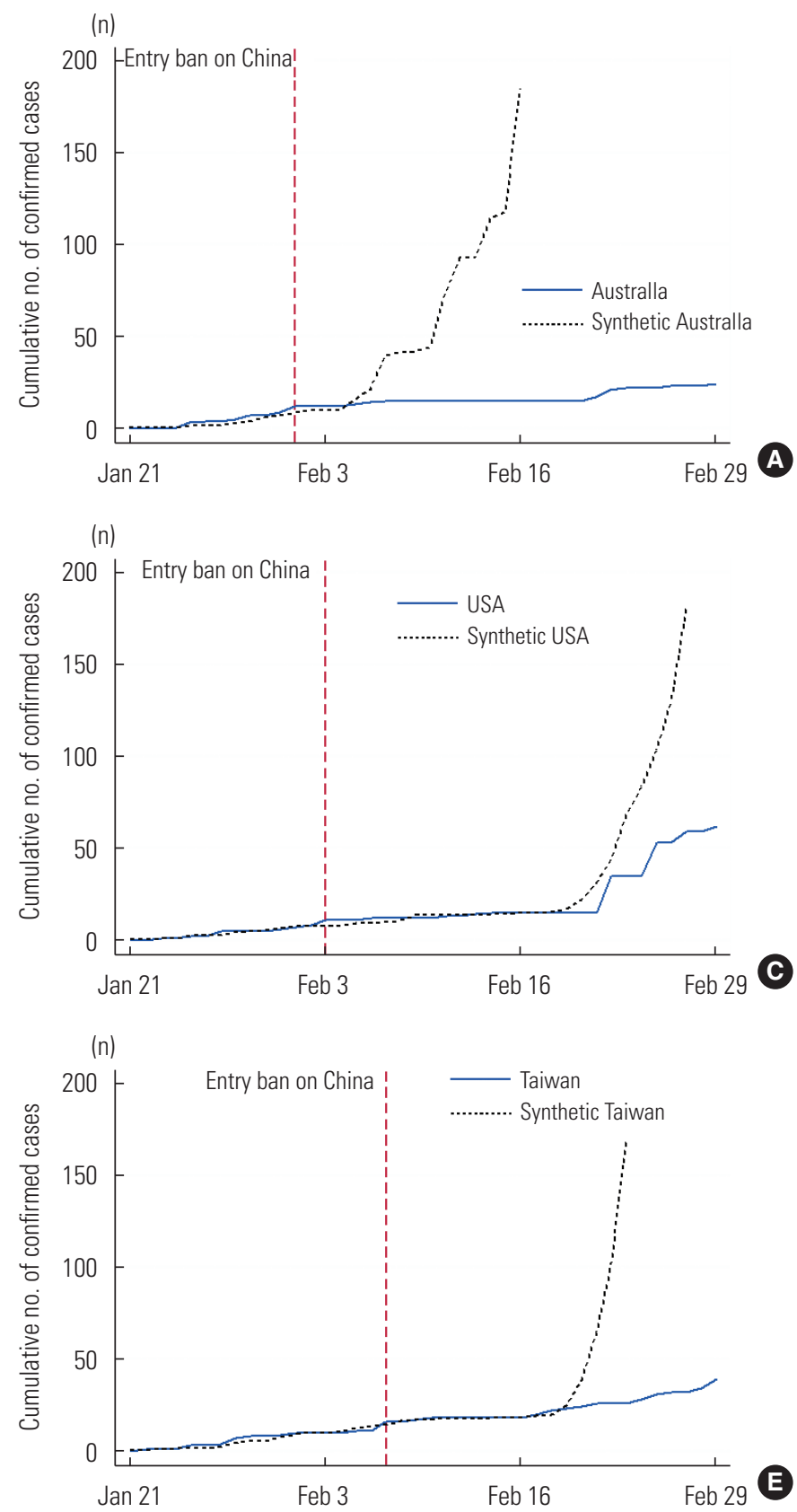
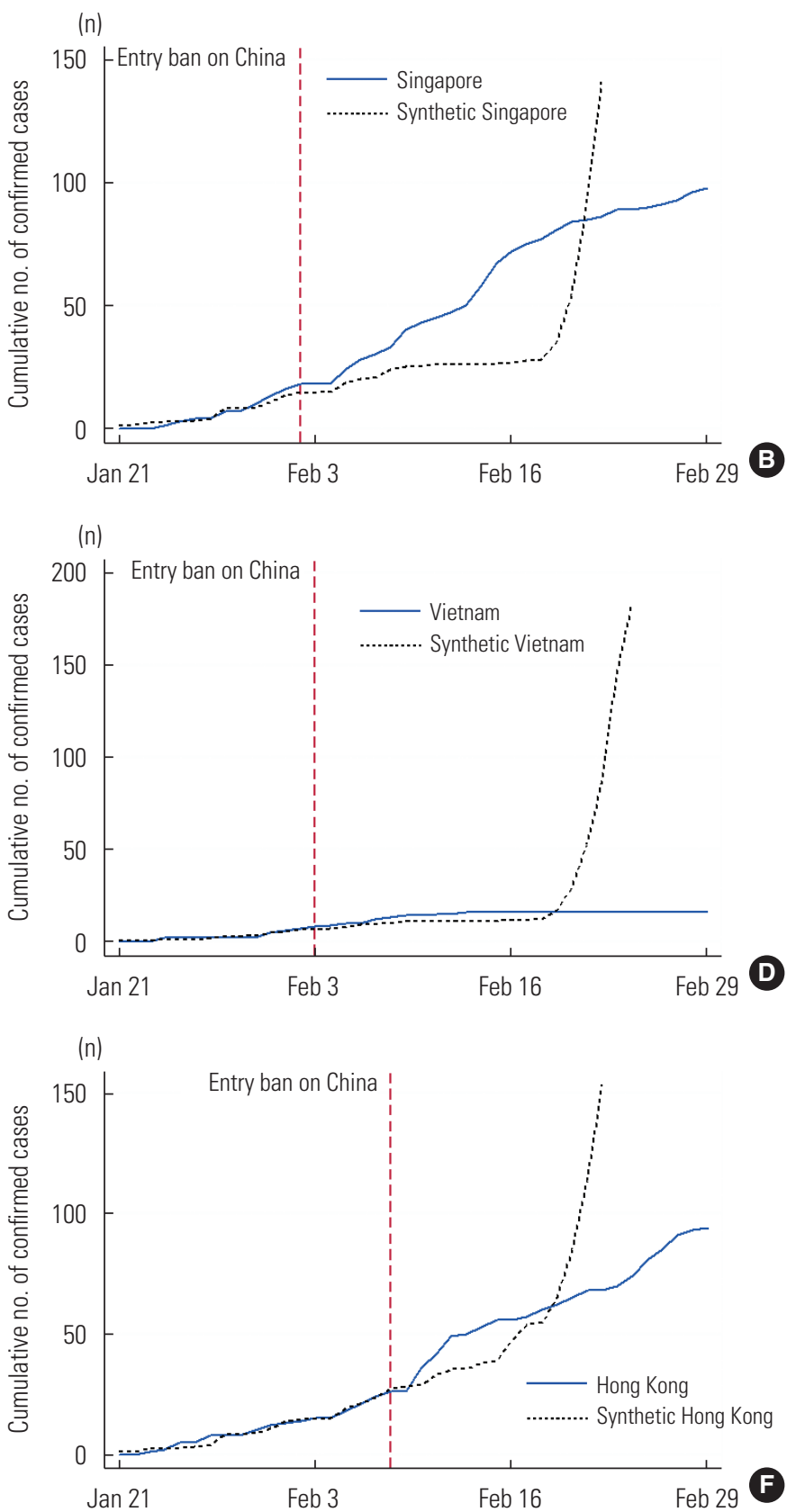

Figure 1. Effects of the entry ban on the coronavirus disease 2019 (COVID-19) epidemic: cumulative number of confirmed cases in the real country (with an entry ban) and synthetic (without an entry ban). (A) Australia, (B) Singapore, (C) USA, (D) Vietnam, (E) Taiwan, and (F) Hong Kong..

cases was estimated to be 331 instead of 62 by the end of February, which is an $81.3 \%$ difference in infected cases: 331 (synthetic United States) versus 62 (real United States).

The next results are for Vietnam, which imposed an entry ban on February 3, 2020 (Figures 1D and 2D). At the time of the policy's implementation, the number of cumulative confirmed cases was only 8 , which is the smallest among the 6 countries that we examined. Synthetic Vietnam was composed of Cambodia (45.5\%), Korea (23.3\%), India (20.6\%), and Thailand (10.6\%). The gap between real and synthetic Vietnam was minimal during the pre-intervention period and continued until February 19, 2020. Starting on February 20, 2020, synthetic Vietnam showed exponential growth and the number of avoidable infected cases sharply increased. By the end of 
(n)
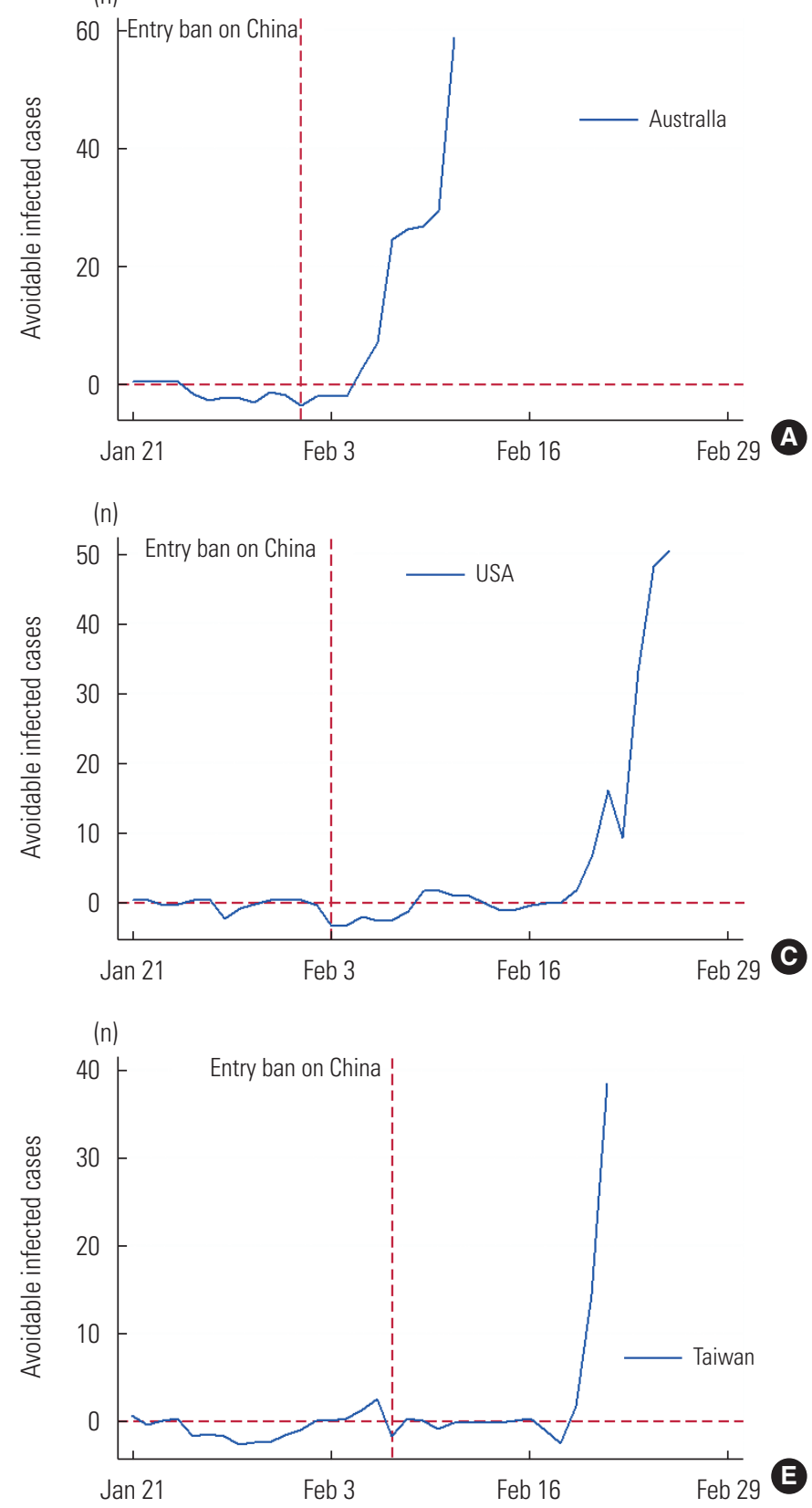

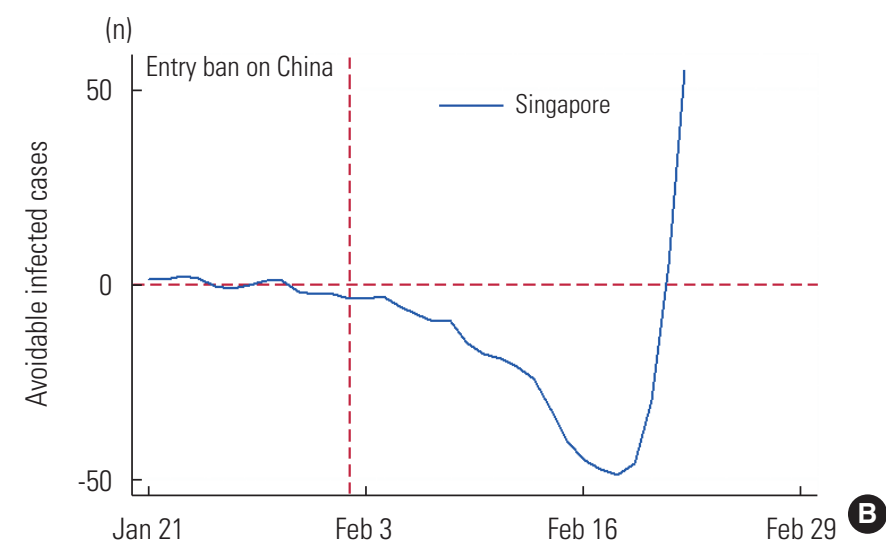

(n)

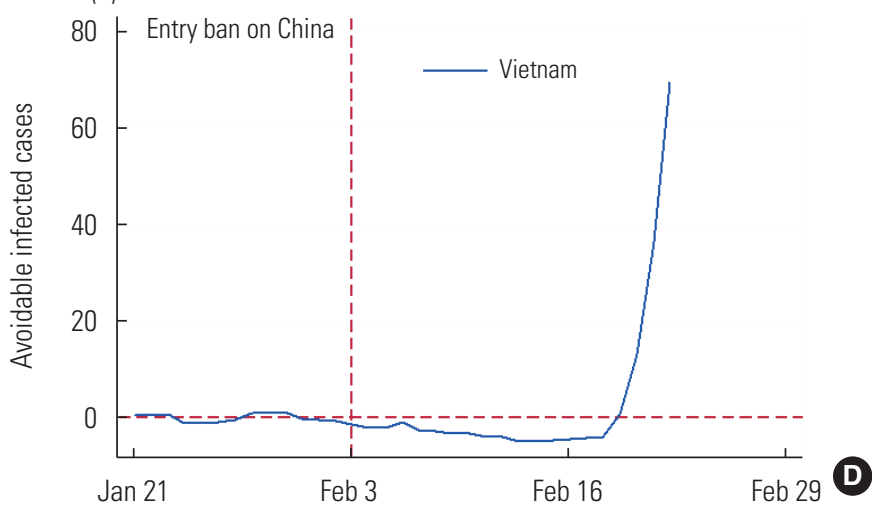

(n)

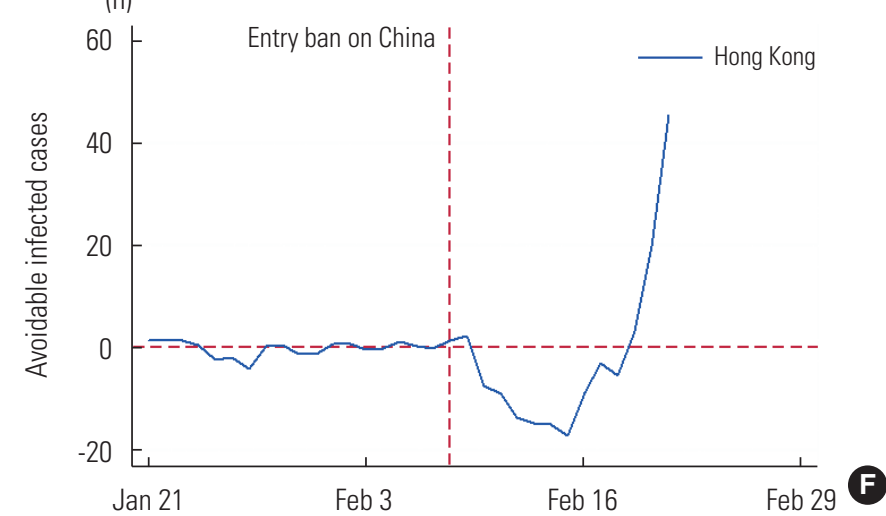

Figure 2. Avoidable infected cases due to the entry ban. This number is calculated by subtracting the number of cases in the real (without an entry ban) from synthetic (with an entry ban) cases (A: Australia, B: Singapore, C: USA, D: Vietnam, E: Taiwan, and F: Hong Kong).

February, 723 cumulative infections were avoided due to the entry ban for Chinese visitors. This reflects a $97.8 \%$ decrease in the number of infected cases: 723 (synthetic Vietnam) versus 16 (real Vietnam).

Taiwan had its first confirmed case on January 22, 2020, and the number of cases slowly increased (Figures $1 \mathrm{E}$ and $2 \mathrm{E}$ ). When Taiwan imposed an entry ban on February 7, 2020, the number of cumulative confirmed cases was 16 . The number remained steady at 18 cases for 7 days until February 16, 2020, when the number of confirmed cases slowly increased. Synthetic Taiwan was composed of Korea (26.0\%), United Arab Emirates (25.2\%), Canada (23.0\%), Thailand (21.1\%), and San Marino (4.7\%). Synthetic Taiwan also mimicked real Taiwan well during the pre-intervention period and the number of 
cumulative confirmed cases increased slowly and steadily. Synthetic Taiwan began to show an exponential growth of infected cases starting on February 21, 2020. By February 29, 2020, 797 cumulative infections were avoided due to the entry ban for Chinese visitors. This is a 95.3\% decrease in infected cases: 836 (synthetic Taiwan) versus 39 (real Taiwan).

Hong Kong, which is connected to mainland China, imposed an entry ban on February 8, 2020 (Figures 1F and 2F). When it imposed the entry ban, the number of cumulative confirmed cases in Hong Kong was 26. Without an entry ban for Chinese visitors, the number of cumulative confirmed cases started to grow exponentially on February 19, 2020. The number of avoidable infected cases became positive on February 19, 2020, and increased exponentially thereafter. By the end of February, 845 infected cases were avoided due to the entry ban. This corresponds to a 90.0\% decrease in infected cases: 939 (synthetic Hong Kong) versus 94 (real Hong Kong).

We performed 2 alternative analyses. First, we added hospital beds per 10000 people as an additional control and found qualitatively similar results, except for the United States. The number of hospital beds in United States was extremely different from that of its donor countries (29 in United States and 38.6 for its donor countries). Second, we estimated the daily numbers of new confirmed cases instead of cumulative confirmed cases. Although the results were similar, there were greater fluctuations due to the presence of more ad hoc variation.

\section{DISCUSSION}

During the COVID-19 outbreak, 93\% of the world's population lived in countries with travel restrictions by the end of March [37]. Here, we showed that border shutdowns in early February significantly decreased the spread of COVID-19. The effects of border shutdowns began to appear, on an average, 13.2 days after policy intervention. This duration can be explained by 2 factors: the incubation period and exponential growth. The incubation period of COVID-19 varies from 2 days to 14 days, according to the WHO. It takes time for an infected (or exposed) individual to travel from China to a destination country and spread the virus. In addition, detection of an infected individual would occur after the number of infected individuals reaches a certain number. Combining these 2 factors accounts for the finding that the effects took 13.2 days to be noticeable. After this period, the countries showed a clear increase in avoidable infected cases. Chinazzi et al. [6] investi- gated the effects of travel limitations on the national and international spread of the epidemic using a global metapopulation disease transmission model. They found that the travel quarantine of Wuhan delayed the epidemic progression by 3 days to 5 days in China. However, this policy reduced case importations by $80 \%$ until mid-February internationally.

Although we focused on the effects of the entry ban in the present study, there are other effective non-pharmaceutical interventions. For example, Korea has used an aggressive approach of testing, tracing, and treatment, and it seems to be working well. Social distancing and wearing a mask are also known to be effective interventions [38]. Flaxman et al. [39] examined the impact of major non-pharmaceutical interventions in 11 European countries and found that current interventions are sufficient to control the epidemic. Haushofer and Metcalf [40] suggested that we need to try to find the best non-pharmaceutical interventions using randomized controlled trials.

Among the countries we evaluated, Australia does not share any borders with other countries, which might have made its situation slightly different. In particular, it may have been easier for Australia to implement a border shutdown since unauthorized border crossings can be more effectively limited.

We used the synthetic control method to quantify a counterfactual situation with no entry bans for visitors from the country that was the primary source of the virus. A limitation of the synthetic control method is the assumption that a country would not change its reaction to COVID-19 over time, and the model does not fully take into account country-specific preventive measures. This assumption may not be realistic later in the pandemic; however, at the beginning of the COVID-19 pandemic, it appears to be valid. Countries later began to impose different shutdown policies. For example, Italy closed schools and universities on March 4, 2020 and implemented a country-wide quarantine on March 9, 2020.

It might be also interesting to compare different degrees of border shutdowns (i.e., border shutdowns targeting travelers from a specific country vs. complete border shutdowns). Unfortunately, these different policies were implemented after mid-March and many other factors also changed at the same time. The synthetic control method cannot isolate these different effects. Therefore, we focused on border shutdowns only in the early stages of the pandemic. By using real-world data instead of a simulation, our results may more closely represent reality. Our findings are informative for public health response planning. 


\section{SUPPLEMENTAL MATERIALS}

Supplemental materials are available at https://doi.org/10. 3961/jpmph.20.332.

\section{CONFLICT OF INTEREST}

The authors have no conflicts of interest associated with the material presented in this paper.

\section{FUNDING}

None.

\section{ACKNOWLEDGEMENTS}

The authors acknowledge Professor Sangsoo Park, Kangheok Go, and Jinyoung Kim for helpful discussions.

\section{AUTHOR CONTRIBUTIONS}

Conceptualization: BK. Data curation: BK, NK. Formal analysis: BK. Funding acquisition: None. Methodology: BK. Project administration: BK. Visualization: BK, NK. Writing - original draft: BK. Writing - review \& editing: BK, NK

\section{ORCID}

Nahae Kang https://orcid.org/0000-0002-7540-9762

Beomsoo Kim https://orcid.org/0000-0001-7468-7448

\section{REFERENCES}

1. Ma J. Coronavirus: China's first confirmed Covid-19 case traced back to November 17. South China Morning Post; 2020 Mar 13 [cited 2020 Jul 1]. Available from: https://www.scmp.com/ news/china/society/article/3074991/coronavirus-chinas-firstconfirmed-covid-19-case-traced-back.

2. Ducharme J. World Health Organization declares COVID-19 a 'pandemic.' here's what that means. TIME; 2020 Mar 11 [cited $2020 \mathrm{Jul}$ 1]. Available from: https://time.com/5791661/whocoronavirus-pandemic-declaration/.

3. World Health Organization. Novel coronavirus (2019-nCov) situation report - 3; 2020 Jan 23 [cited 2020 Mar 10]. Available from: https://www.who.int/docs/default-source/coronaviruse/ situation-reports/20200123-sitrep-3-2019-ncov.pdf?sfvrsn= d6d23643_8.

4. Crossley G. Wuhan lockdown 'unprecedented', shows commitment to contain virus: WHO representative in China. Reuters; 2020 Jan 23 [cited 2020 Mar 10]. Available from: https://www. reuters.com/article/us-china-health-who/wuhan-lockdownunprecedented-shows-commitment-to-contain-virus-whorepresentative-in-china-idUSKBN1ZM1G9.

5. China coronavirus: lockdown measures rise across Hubei province. BBC; 2020 Jan 23 [cited 2020 Mar 10]. Available from: https://www.bbc.com/news/world-asia-china-51217455.

6. Chinazzi M, Davis JT, Ajelli M, Gioannini C, Litvinova M, Merler $S$, et al. The effect of travel restrictions on the spread of the 2019 novel coronavirus (COVID-19) outbreak. Science 2020; 368(6489):395-400.

7. Bajardi P, Poletto C, Ramasco JJ, Tizzoni M, Colizza V, Vespignani A. Human mobility networks, travel restrictions, and the global spread of 2009 H1N1 pandemic. PLoS One 2011;6(1):e16591.

8. Poletto C, Gomes MF, Pastore y Piontti A, Rossi L, Bioglio L, Chao DL, et al. Assessing the impact of travel restrictions on international spread of the 2014 West African Ebola epidemic. Euro Surveill 2014;19(42):20936.

9. Epstein JM, Goedecke DM, Yu F, Morris RJ, Wagener DK, Bobashev GV. Controlling pandemic flu: the value of international air travel restrictions. PLoS One 2007;2(5):e401.

10. Hong Kong and Chinese nationals banned from entering Kuwait. GDIN Online; 2020 Jan 31 [cited 2020 Mar 10]. Available from: http://www.gdnonline.com/Details/749636/Hong-Kongand-Chinese-nationals-banned-from-entering-Kuwait.

11. Australian Government. COVID-19 and the border [cited 2020 Feb 1]. Available from: https://www.homeaffairs.gov.au/newsmedia/current-alerts/novel-coronavirus.

12. Ministry of Health. Extension of precautionary measures to minimise risk of community spread in Singapore; 2020 Jan 31 [cited 2020 Mar 10]. Available from: https://www.moh.gov. sg/news-highlights/details/extension-of-precautionary-measures-to-minimise-risk-of-community-spread-in-singapore.

13. Trump DJ. Proclamation on suspension of entry as immigrants and nonimmigrants of persons who pose a risk of transmitting 2019 novel coronavirus. The White House; 2020 Jan 31 [cited 2020 Mar 10]. Available from: https://www.whitehouse.gov/ presidential-actions/proclamation-suspension-entry-immigrants-nonimmigrants-persons-pose-risk-transmitting-2019novel-coronavirus/.

14. Embassy of the Republic of Korea in Vietnam. Special Safety 
Notice No. 5 on new coronavirus infections; 2020 [cited 2020 Mar 10]. Available from: http://overseas.mofa.go.kr/vn-ko/ $\mathrm{brd} / \mathrm{m} \_2203 / \mathrm{view} . \mathrm{do} ? \mathrm{seq}=1345306 \& \mathrm{srchFr}=\& \mathrm{amp} ; \mathrm{srchTo}=$ \&amp;srchWord $=\% E C \% A 4 \% 91 \% E A \% B 5 \% A D \& a m p ; s r c h T p=$ 1\&amp;multi_itm_seq=0\&amp;it\%E2\%80\%A6 (Korean).

15. Ministry of Foreign Affairs. Starting February 7, 2020, the Republic of China (Taiwan) will implement a temporary measure prohibiting foreign nationals who in the previous 14 days have visited or resided in the People's Republic of China (PRC), including Hong Kong and Macao, from entering Taiwan; 2020 Feb 6 [cited 2020 Mar 10]. Available from: https://www.mofa. gov.tw/en/News_Content.aspx?n=1EADDCFD4C6EC567\&sm $s=5 B 9044 C F 1188 \mathrm{EE} 23 \& s=$ EFB88BECEB5CCC 92 .

16. Consulate General of the Republic of Korea in Hong Kong. Notice on the new coronavirus; 2020 Feb 8 [cited 2020 Mar 10]. Available from: http://overseas.mofa.go.kr/hk-ko/brd/m_1504/ view.do?seq $=1332689 \&$ srchFr $=$ \&amp;srchTo = \&amp;srchWo rd =\&amp;srchTp=\&amp;multi_itm_seq =0\&amp;itm_seq_ \%E2\%80\%A6 (Korean).

17. Ministry of Health. Statement No. (6) on novel corona virus in China; 2020 Feb 22 [cited 2020 Mar 10]. Available from: https:// moh.gov.om/en/web/guest/media-center-display-page/-/asset_publisher/NmYvyVmbbJDi/content/--1222/pop_up? 101_INSTANCE_NmYvyVmbbJDi_v\%E2\%80\%A6.

18. Interior ministry announces total ban on all travelers who have visited China within 14 days of their arrival in Bahrain. Daily Tribune News of Bahrain; 2020 Feb 13 [cited 2020 Sep 18]. Available from: https://www.newsofbahrain.com/bahrain/61448. html.

19. Ministry of Health, State of Israel. Sea and land points of entry closed off; 2020 Feb 2 [cited 2020 Jul 1]. Available from: https:// www.health.gov.il/English/News_and_Events/Spokespersons_ Messages/Pages/02022020_2.aspx.

20. New Zealand Government. New Zealand to restrict travel from China to protect against coronavirus; 2020 Feb 2 [cited 2020 Jul 1]. Available from: https://www.beehive.govt.nz/release/ new-zealand-restrict-travel-china-protect-against-coronavirus.

21. Awadalla N, Rasheed A. Iraq bans entry of foreigners coming from China over coronavirus fears - ministry. Reuters; 2020 Feb 2 [cited 2020 Jul 1]. Available from: https://www.reuters. com/article/china-health-iraq/iraq-bans-entry-of-foreignerscoming-from-china-over-coronavirus-fears-ministry-idUSC6N271029.

22. Philippine Information Agency. Bl to implement expansion of travel ban; 2020 Feb 3 [cited 2020 Jul 1]. Available from: https:// pia.gov.ph/index.php/news/articles/1033854.

23. Embassy of the Republic of Korea in Russia. A notice for the safety of overseas Koreans; 2020 Feb 21 [cited 2020 Jul 1]. Available from: http://overseas.mofa.go.kr/ru-ko/brd/m_7333/ view.do?seq $=1346915 \&$ srchFr $=\& a m p ; s r c h T o=\& a m p ; s r c h W o$ rd =\&amp;srchTp =\&amp;multi_itm_seq=0\&amp;itm_seq_ \%E2\%80\%A6\%201 (Korean).

24. Minister of works halts arrivals from countries with coronavirus outbreak. National News Agency; 2020 Feb 28 [cited 2020 Jul 1]. Available from: http://nna-leb.gov.lb/en/show-news/ 112952/Minister-of-Works-halts-arrivals-from-countries-withCoronavirus-outbreak.

25. Embassy of the Republic of Korea to the Republic of Lebanon. Embassy safety notice (Lebanon entry regulation); 2020 Mar 3 [cited 2020 Jul 1]. Available from: http://overseas.mofa.go. $\mathrm{kr} / \mathrm{lb}-\mathrm{ko} / \mathrm{brd} / \mathrm{m} \_10825 / \mathrm{view} . \mathrm{do} ? \mathrm{seq}=1338202 \& \mathrm{srchFr}=$ \&am p;srchTo =\&amp;srchWord =\&amp;srchTp =\&amp;multi_itm_ seq $=0 \& a m p ; i t m \_s e q$ (Korean).

26. Abadie A, Gardeazabal J. The economic costs of conflict: a case study of the Basque Country. Am Econ Rev 2003;93(1):113-132.

27. Abadie A. Using synthetic controls: feasibility, data requirements, and methodological aspects. J Econ Lit 2020 (in press).

28. Kreif N, Grieve R, Hangartner D, Turner AJ, Nikolova S, Sutton $M$. Examination of the synthetic control method for evaluating health policies with multiple treated units. Health Econ 2016; 25(12):1514-1528.

29. Abadie A, Diamond A, Hainmueller J. Synthetic control methods for comparative case studies: estimating the effect of California's tobacco control program. J Am Stat Assoc 2010;105 (490):493-505.

30. World Health Organization. Coronavirus disease 2019 (COVID19) situation report - 49; 2020 Mar 9 [cited 2020 Jul 1]. Available from: https://www.who.int/docs/default-source/coronaviruse/situation-reports/20200309-sitrep-49-covid-19.pdf? sfvrsn=70dabe61_4.

31. World Bank. Indicators; 2020 Mar 18 [cited 2020 Jul 1]. Available from: https://data.worldbank.org/indicator?tab=all.

32. National Statistics. Statistical yearbook of the Republic of China 2018; 2019 [cited 2020 Mar 18]. Available from: https:// eng.stat.gov.tw/ct.asp?xltem $=44665 \& \mathrm{ctNode}=6340 \& \mathrm{mp}=5$.

33. Department of Health. Health facts of Hong Kong 2019 edition [cited 2020 Mar 18]. Available from: https://www.dh.gov.hk/ english/statistics/statistics_hs/files/Health_Statistics_pamphlet_E.pdf.

34. Food and Health Bureau. Hong Kong's domestic health ac- 
counts (DHA); 2019 [cited 2020 Mar 18]. Available from: https:// www.fhb.gov.hk/statistics/download/dha/en/dha_summary_ report_1718.pdf.

35. World Tourism Organization. Yearbook of tourism statistics, data 2014 - 2018, 2020 edition. Madrid: World Tourism Organization; 2020, p. 7-973.

36. It's becoming difficult to get Chinese visas: Pakistan. Business Standard; 2017 Sep 2 [cited 2020 Jul 1]. Available from: https:// www.business-standard.com/article/international/it-s-becoming-difficult-to-get-chinese-visas-pakistan-117090200487_1. html.

37. Connor P. More than nine-in-ten people worldwide live in countries with travel restrictions amid COVID-19. Pew Research
Center; 2020 Apr 1 [cited 2020 Jul 1]. Available from: https:// www.newsbreak.com/news/1539216718347/more-than-ninein-ten-people-worldwide-live-in-countries-with-travel-restrictions-amid-covid-19.

38. Ryu S, Ali ST, Jang C, Kim B, Cowling BJ. Effect of nonpharmaceutical interventions on transmission of severe acute respiratory syndrome coronavirus 2, South Korea, Emerg Infect Dis 2020. doi: https://doi.org/10.3201/eid2610.201886.

39. Flaxman S, Mishra S, Gandy A, Unwin HJ, Mellan TA, Coupland $\mathrm{H}$, et al. Estimating the effects of non-pharmaceutical interventions on COVID-19 in Europe. Nature 2020;584(7820):257-261.

40. Haushofer J, Metcalf CJ. Which interventions work best in a pandemic? Science 2020;368(6495):1063-1065. 